\title{
ReMIによる新たなレドックス分子イメージング法の開発と応用
}

\author{
兵藤文紀, ${ }^{*}$ 伊藤 慎 治, 内 海 英 雄
}

\section{Redox Molecular Imaging Using ReMI}

\author{
Fuminori Hyodo, ${ }^{*}$ Shinji Ito, and Hideo Utsumi \\ Innovation Center for Medical Redox Navigation, Kyushu University; \\ 3-1-1 Maidashi, Higashi-ku, Fukuoka 812-8582, Japan.
}

(Received September 26, 2014)

\begin{abstract}
Tissue redox status is one of the most important parameters to maintain homeostasis in the living body. Numerous redox reactions are involved in metabolic processes, such as energy production in the mitochondrial electron transfer system. A variety of intracellular molecules such as reactive oxygen species, glutathione, thioredoxins, NADPH, flavins, and ascorbic acid may contribute to the overall redox status in tissues. Breakdown of redox balance may lead to oxidative stress and can induce many pathological conditions such as cancer, neurological disorders, and aging. Therefore imaging of tissue redox status and monitoring antioxidant levels in living organisms can be useful in the diagnosis of disease states and assessment of treatment response. In vivo redox molecular imaging technology such as electron spin resonance imaging (ESRI), magnetic resonance imaging (MRI), and dynamic nuclear polarization (DNP) -MRI (redox molecular imaging; ReMI) is emerging as a viable redox status imaging modality. This review focuses on the application of magnetic resonance technologies using MRI or DNP-MRI and redox-sensitive contrast agents.
\end{abstract}

Key words_ _ redox imaging; dynamic nuclear polarization; nitroxyl radical; magnetic resonance imaging

\section{1. はじめに}

生体レドックスとは生体内で生じる酸化（oxidation）還元（reduction）反応を示す。生体はレドッ クス反応を介し無数の代謝によりホメオスタシスを 維持している．例えば解糖系，クエン酸回路，電子 伝達系が関与するエネルギー産生は生体内の最も重 要な代謝経路である.ミトコンドリアではクエン酸 回路で産生された nicotinamide adenine dinucleotide（NADH） やコハク酸などの基質を用い電子伝 達系において電子の授受を利用して ATP が生成さ れる．その過程で漏れ出た電子と酸素との反応で活 性酸素種 (reactive oxygen species; ROS) の1つで あるスーパーオキシド $\left(\mathrm{O}_{2}^{-\cdot}\right)$ が生成されるため, ミトコンドリアは生体内の主要な ROS 生成源であ

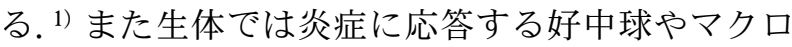
ファージなどの炎症細胞の浸潤・活性化に伴い

九州大学先端融合医療レドックスナビ研究拠点 (T8128582 福岡市東区馬出 3-1-1)

*e-mail: hyodof@redoxnavi.med.kyushu-u.ac.jp 本総説は, 日本薬学会第 134 年会シンポジウムS04 で 発表した内容を中心に記述したものである.
ROS が産生，また薬物代謝酵素（シトクロム P-450）等による異物代謝においても ROS が産生 されることが知られている。 そして ROS の過剩生 成，それに対する防御系であるグルタチオンやアス コルビン酸などの抗酸化物質，グルタチオンペルオ キシダーゼやスーパーオキシドジスムターゼ（superoxide dismutase; SOD）などの抗酸化酵素の増 減はレドックスバランスの破綻を誘導する。近年, 糖尿病やがん，脳疾患などの生活習慣病や，精神疾 患等の病態変化に ROS や抗酸化分子・酵素の関与 が報告されている。したがって生体レドックス状態 の非侵襲的可視化技術はこれらの病態における新た な診断・創薬ツールとしての展開が期待される。

超音波診断装置や核医学検査 positron emission tomography (PET) や single photon emission computed tomography (SPECT), computed tomography (CT), magnetic resonance imaging (MRI), 蛍光 · 発光イメージング法などは臨床ないし実験動物を対 象に生体機能や組織構造を描写する画像化装置とし て活用されている，特にがん分野においてイメージ ング (可視化) 技術は治療計画の立案，部位の特定， 
治療効果の判定など必要不可欠な情報を与える. MRI に代表される磁気共鳴現象を利用した磁気共 鳴イメージング法は，核や電子が持つ磁気モーメン トと磁場との相互作用により生じたエネルギー準位 間の電磁波遷移を観測の対象とする。核スピンを観 測対象とする場合には MRI を用い，電子スピンを 対象とする場合には電子スピン共鳴装置（electron spin resonance; ESR）が用いられている。磁気共 鳴イメージングでは周波数が低く体内透過性の高い ラジオ波若しくはマイクロ波を用いるのでヒトや動 物において深部計測が可能である。近年，われわれ の拠点で開発を進めている動的核偏極（dynamic nuclear polarization; DNP）を利用する DNP-MRI 法は，フリーラジカルの電子スピンを ESR 遷移さ せ，電子スピンと核スピンの双極子相互作用により 核スピンが偏極する現象（オーバーハウザー効果） を利用し MRI の感度を劇的に上昇させラジカルの 情報を得る技術である. ${ }^{2)} 1988$ 年にアバディーン大 学の Lurie らは，この効果を利用した MRI（proton electron double resonance imaging; PEDRIないし overhauser enhanced magnetic resonance imaging; OMRI と呼ばれている)，すなわち，水分子近傍の フリーラジカルを励起させることで増幅したプロト ン信号を MRI で画像化する方法を報告した。 ${ }^{3)}$ その 後 Philips 社よりプロトタイプ機が世界で数台販売 され，そのうちの一台が九州大学コラボステーショ ンに導入された. Figure 1 は Philips 社が試作した PEDRI（DNP-MRI）装置と日本レドックス社が製 作したベンチトップ型 DNP-MRI 装置（Keller）を 示す。DNP-MRI によるラジカル画像は MRI と同 等の空間分解能と時間分解能を有し, 高磁場型の DNP-MRI は，鮮明な解剖学的情報も同時に得るこ とが可能である。 DNP-MRI 法は近年急速に研究が 進夕，様々な応用例が示されている，例えばトリア リルメチルラジカル, ${ }^{4)}$ あるいはニトロキシルラジ

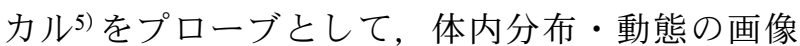
化，腫瘍内の酸素イメージングの)や血管透過性の同 時検出, ${ }^{7)}$ 脳梗塞モデル動物8) のレドックス解析な どが報告されている．われわれは DNP-MRI 装置 を導入する際に，異なる核種のラジカルを同時分離 画像化する方法を新たに測定シーケンスに組み込

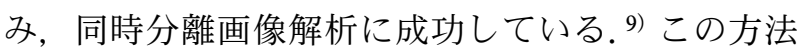
は後述するように同一組織あるいは細胞の内外のレ

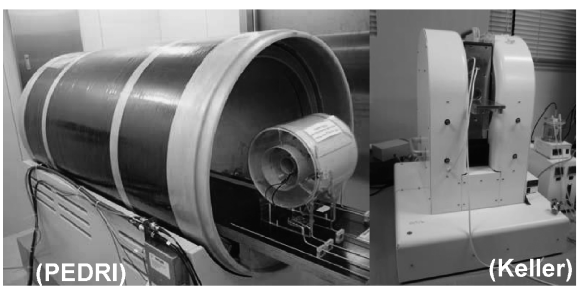

DNP-MRI systems

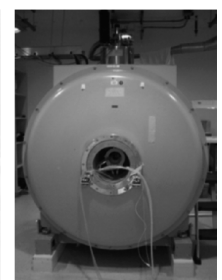

4.7T MRI
Fig. 1. Picture of Magnetic Resonance Imaging Systems Prototype of Philips PEDRI imager, Bench-top type of DNP-MRI (Keller) and 4.7T MRI.
A)

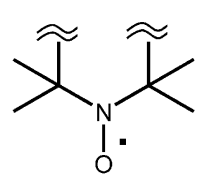

Oxidized form

- Nitroxyl radical

-EPR detectable

- DNP positive

$\cdot \mathrm{T}_{1}$ shortening

B)<smiles>[2H]C([2H])([2H])C([2H])([2H])C1(C(=O)O)N([O])C([2H])(C([2H])([2H])[2H])C([2H])([2H])C(=O)C1([2H])[2H]</smiles>

D)

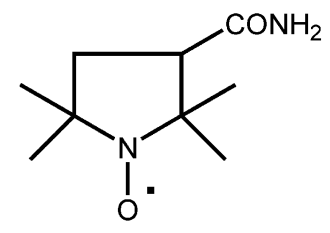

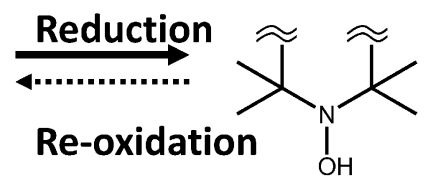

Reduced form

- Hydroxylamine - EPR silent - DNP negative - Non- $T_{1}$ shortening

C)<smiles>CC1(C)CC(=O)CC(C)(C)N1[O]</smiles><smiles>CC1(C)CC(O)CC(C)(C)N1[O]</smiles>

Fig. 2. Reversible One-electron Reduction/Oxidation Showing the Inter-conversion and the Molecular Structure of the Four Nitroxides, B) $\left.{ }^{15} \mathrm{~N}-\mathrm{PDT}, \mathrm{C}\right)$ Tempone, D) CarbamoylPROXYL and E) Tempol Used in This Work

ドックス反応を分けて解析することが可能であり, 今後酸化ストレス疾患モデルを用いた様々な病態応 用研究への展開が期待できる。本総説では，MRI と DNP-MRI を用いた磁気共鳴レドックスイメー ジングについて概説する.

2.レドックス応答磁気共鳴プローブ : ニトロキ シルラジカル

ニトロキシルラジカルは分子内に安定ラジカルを 有し，フリーラジカルとの反応性や抗酸化作用を示 すことが知られている (Fig. 2). ${ }^{10,11)}$ また，このラ 


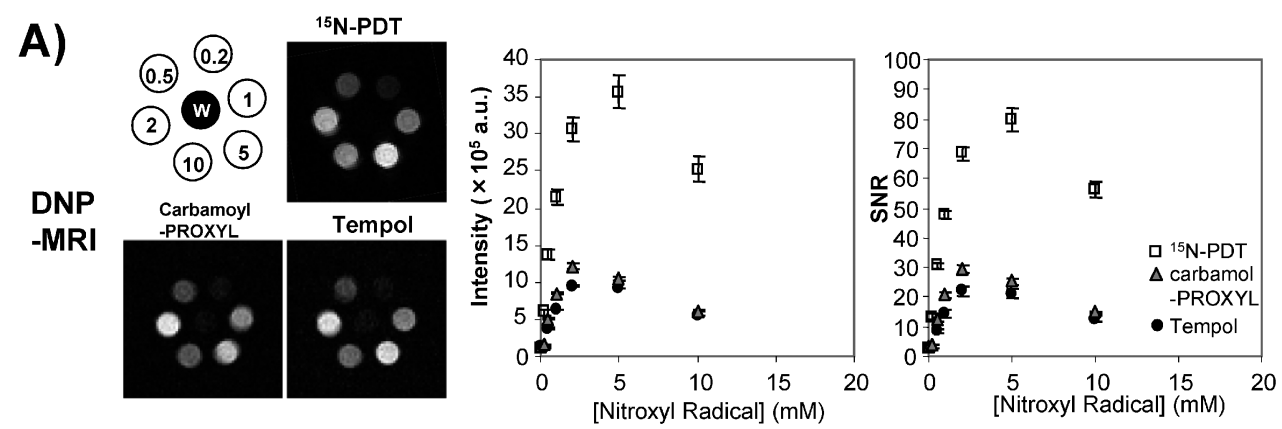

B)

MRI
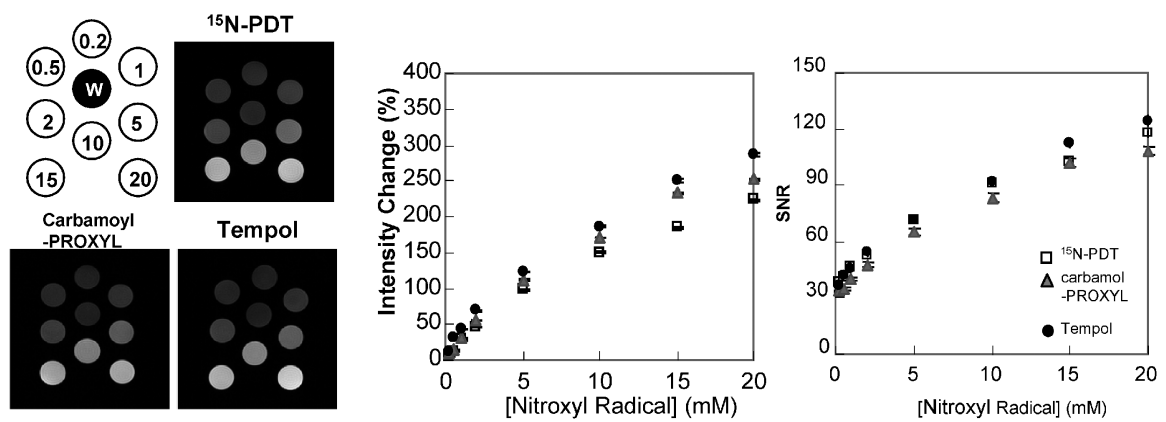

Fig. 3. Comparison of Intensity Change and SNR of Nitroxyl Radicals

The intensity change (left column) and SNR (right column) of nitroxides in A) DNP-MRI and B) MR images are showed. The intensity was calculated for a select ROI from DNP-MRI and MR image of each nitroxyl radical. The intensity change (\%) of MRI was calculated based on the intensity of center phantom containing pure water. Number of experiments are 3. (Cited from Hyodo et al. J Magn Reson. 2008 190 (1) : 105-12. 2007)

ジカルはレドックス反応性を示すとともに磁気共鳴 法における造影剤としての役割も果たすためニトロ キシルラジカルは磁気共鳴イメージング（ESRI, MRI, DNP-MRI）におけるレドックス解析のため のプローブとして活用されてきた. ${ }^{12-17)}$ ニトロキシ ルラジカルは生体内で種々のレドックス反応を媒介 することがこれまでの研究で明らかになっており， 生体内では還元されラジカルを失い主にヒドロキシ ルアミン体（非磁性）となる。生体内のレドックス 状態に応じて画像強度の消失速度が変化するためこ の消失速度をレドックス反応速度として解析してい る。ニトロキシルラジカルには局在性や反応性，機 能性の向上を指向した多くの誘導体が存在し，これ らを目的に応じ使い分けることで反応部位や，機能 などの異なる生体応答を解析することが可能とな る。例えば 4-hydroxy Tempo (Tempol) や methoxycarbonyl-PROXYL（MC-PROXYL）は高い細胞 膜透過性を持ち, 分布した臓器・組織の細胞内レ ドックス反応を鋭敏に描写する。一方，細胞膜非透 過性ニトロキシルラジカルである carboxy-PROXYL は，細胞内には移行せず血管内を滞留するため 血液中のレドックス解析に適している。ゆえに両者 （細胞膜透過・非透過）のスピンプローブを共投与
したマウスを DNP-MRI で同時分離画像解析すれ ば，同一個体における細胞内・外のレドックス変動 の解析が可能である. ${ }^{18)}$

ニトロキシルラジカルは上述したように分子内に 不対電子を持つことから MRI の縦緩和撮像法（ $\mathrm{T}_{1}$ 強調撮像）において造影効果（ $\mathrm{T}_{1}$ 緩和時間短縮効

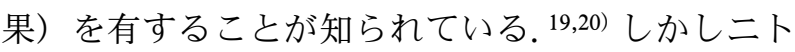
ロキシルラジカルの高い生体内反応性は造影（目的 の臓器で安定したコントラストを得る）という観点 からは不都合であった。一方，ガドリニウム系の造 影剂は生体内で安定かつ造影効果（緩和度）がニト ロキシルラジカルに比べて高いために臨床で用いら れている。そこでわれわれは反応性に富むニトロキ シルラジカルの生体レドックス状態を可視化するた めの MRI 造影剂としての活用性を模索し担がんモ デルマウスにおけるレドックス状態の可視化に成功 している. ${ }^{18,21)}$

3. フリーラジカル溶液含有ファントムの可視化

Figure 3 は MRI と DNP-MRI におけるラジカル 濃度と画像強度の関係を調べたものである。疑似試 料（ファントム）に 0.2-20 mM の ${ }^{15} \mathrm{~N}-\mathrm{PDT}$, Tempol, carbamoyl-PROXYL 溶液を充填し MRI 若し くは DNP-MRI で撮像した。DNP-MRI, MRI とも 


\begin{abstract}
A)

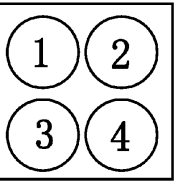

B)
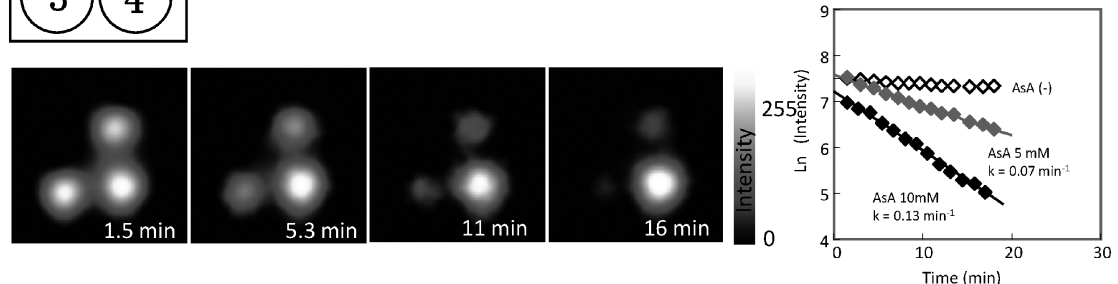

C)

MRI
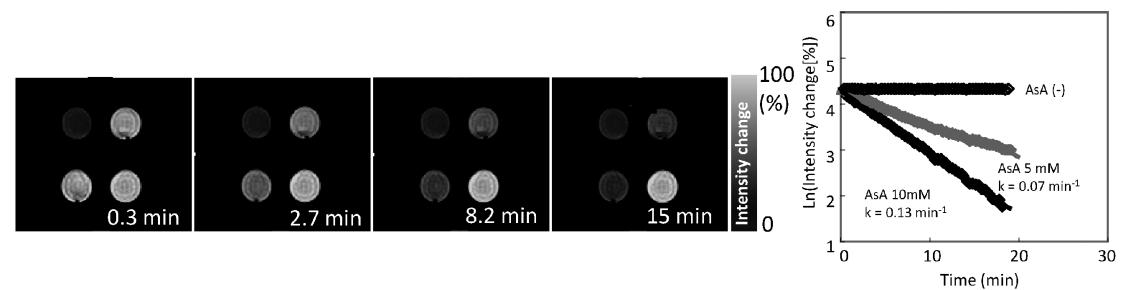

D)
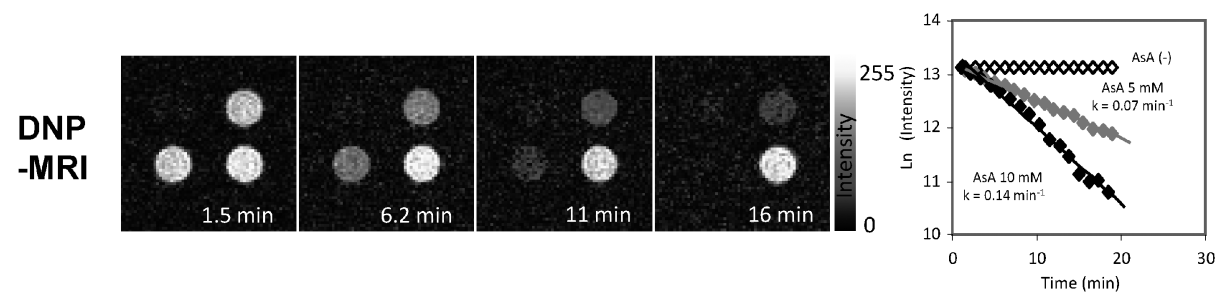

Fig. 4. Comparison of Image Intensity Decay among Three Magnetic Resonance Modalities

A) Schematic of the phantoms: Tube 1, PBS; Tube 2, 2 mm carbamoyl-PROXYL and 5 mм AsA; Tube 3, 2 mm carbamoyl-PROXYL and $10 \mathrm{~mm}$ AsA; Tube 4, 2 mM carbamoyl-PROXYL. Time course images and decay slope of B) ESRI, C) MRI, D) DNP-MRI were obtained. After addition of AsA/PBS solution, the ESRI or DNP-MRI measurements were started immediately and continuously measured up to $20 \mathrm{~min}$. In the case of MRI, AsA/PBS was added using PE-10 tube 2 min after scanning was started. Therefore, time zero in the MRI experiment represents the time at addition of AsA solution. The experiments were repeated three or four times using with freshly prepared solutions. Semi-logarithmic plots of the time course of MRI signal change in the region of interest (ROI: $10 \times 10$ pixels) were used for decay rate calculation using imageJ software. Decay rate constants were obtained from the slope of linear portion of the decay curves.
\end{abstract}

にラジカルを含む場合には PBS のみのファントム に比べ画像強度が上昇した. ${ }^{22)}$ それぞれのファント ムで関心領域（region of interests; ROI）を設定し 画像強度をプロットした場合, DNP-MRIにおいて は ${ }^{15} \mathrm{~N}-\mathrm{PDT}$ を除くニトロキシルラジカルで $3 \mathrm{~mm}$ で強度が最大となり, それ以上の濃度ではラジカル 相互作用による線幅のブロードニングにより画像強 度の減少が観察された。 ${ }^{15}$ N-PDT は狭線幅を持つ ニトロキシルラジカルであるが，この場合では 5 mM が最大值であった。一方，MRI 法においては すべてのニトロキシルラジカルで同様の挙動を示 し, ラジカル濃度として $20 \mathrm{~mm}$ まで画像強度が上 昇した。これらの結果より MRI 法ではニトロキシ ルラジカルの線幅に画像コントラストが依存しない ため, ESRI や DNP-MRI では感度の低下が懸念さ れるような線幅の広いプローブも造影剂として活用 できることが示唆された。

次に 3 種類（ESRI, MR, DNP-MRI）の磁気共鳴
イメージングによるレドックス反応の可視化を評価 するために, 2 mM carbamoyl-ROXYL を充填した ファントムに 5 若しくは $10 \mathrm{~mm}$ のアスコルビン酸 （AsA）を加え, 磁気共鳴イメージング法にて経時 的に撮像した。 AsA は cabamoyl PROXYL のラジ カルを濃度依存的に消去する. Figure 4 には 3 種の 磁気共鳴装置でファントムを撮像した結果を示す。 すべての装置において 2 mM の carbamoyl-PROXYL を含むファントムが可視化されていることがわ かる. ESRI 法は直接ラジカルを検出するという利 点はあるものの, ラジカルのスペクトル線幅は画像 解像度に影響するため, ニトロキシルラジカルのよ うに比較的線幅の広いプローブを用いる場合には空 間解像度も低くなる。また画像強度は, AsAの添 加によりニトロキシルラジカルが還元されるため時

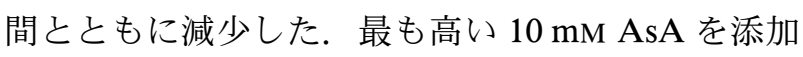
したファントムでは画像強度が有意に消失した。こ のとき, 画像強度の変化を片対数プロットし消失速 


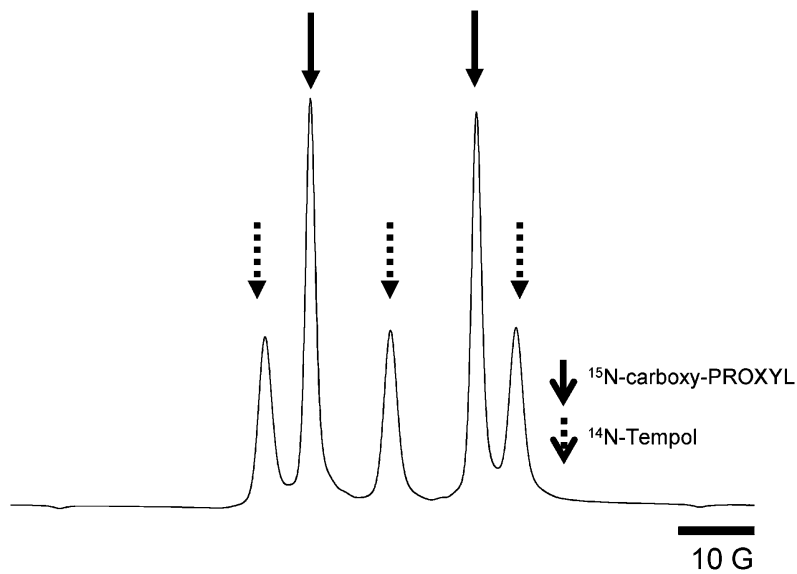

Fig. 5. X-band ESR Spectra of ${ }^{14} \mathrm{~N}-,{ }^{15} \mathrm{~N}$-nitroxyl Radical

度を算出すると，すべての装置において AsA 添加 ファントムの消失速度は同じ傾向を示したことから 3 種の磁気共鳴装置のどれにおいても同様にレドッ クス反応を検出できることが示された. ${ }^{22)}$

4. DNP-MRI によるレドックスイメージング

DNP-MRI は前述した通りMRI と同程度の空間 解像度を維持しながらフリーラジカルの情報を得る ことができる。このときフリーラジカル分子に対す
る電子スピン励起（ESR ON）を行うに当たり，ラ ジカル分子のスペクトルのピークに共鳴磁場を設定 する. ${ }^{9)}$ ゆえに，フリーラジカル分子の電子スピン 共鳴スペクトルのピークが重複しない場合は，励起 磁場をそれぞれのラジカル分子のピークに設定し電 子スピン励起すれば複数のラジカルを分離画像化で きる. Figure 5 には ${ }^{14} \mathrm{~N}$ と ${ }^{15} \mathrm{~N}$ 標識のニトロキシル ラジカル混合液を X-Band ESR で計測して得たス ペクトルを示す。 ${ }^{14} \mathrm{~N},{ }^{15} \mathrm{~N}$ の核スピンはそれぞれ 1 と $1 / 2$ であり, ${ }^{14} \mathrm{~N}$ ニトロキシルラジカルからは 3 本のピークが, ${ }^{15} \mathrm{~N}$ 標識体からは 2 本のピークが得 られた。この場合 ${ }^{14} \mathrm{~N}$ ニトロキシルラジカルと ${ }^{15} \mathrm{~N}$ 標識体のピークに相当する磁場で交互に電子スピン 励起を行えば 2 種のラジカルが分離画像化できるこ とになる. 2 種類のラジカルの分離画像解析の例を 示す (Fig. 6)。ファントムの組成は(1) $1 \mathrm{~mm}$ の ${ }^{15} \mathrm{~N}$ carbamoyl-PROXYL, (2) $1 \mathrm{mM}{ }^{14} \mathrm{~N}$ Tempol, (3)それ らの混合液（終濃度はそれぞれ $1 \mathrm{mM} ） に 10 \mathrm{mM}$ AsA を添加したものである.このファントムを ${ }^{14} \mathrm{~N}$ の中心線の共鳴周波数である $456 \mathrm{MHz}$ と ${ }^{15} \mathrm{~N}$ 標識 体の高磁場側ピークである $480 \mathrm{MHz}$ で交互に周波

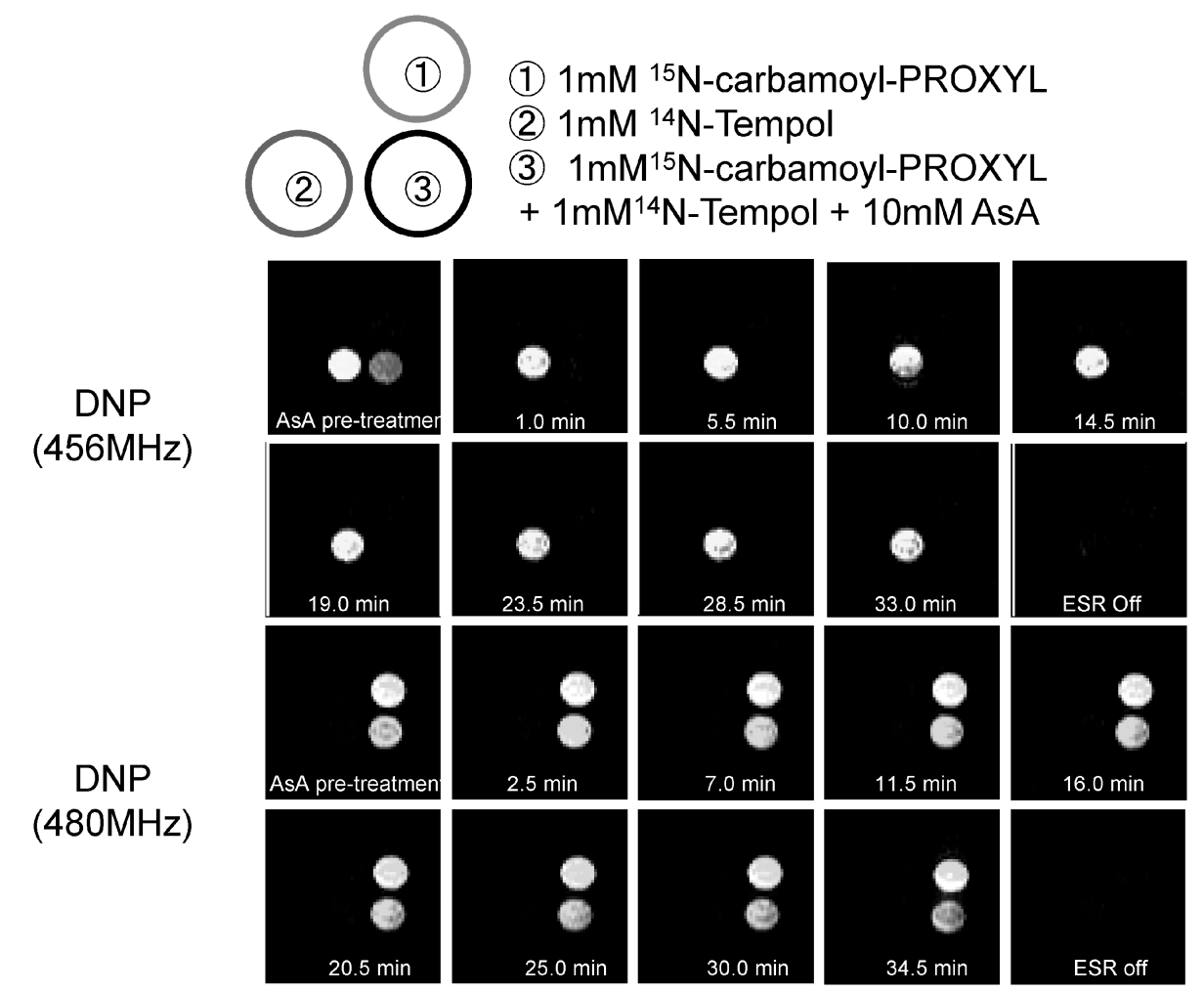

Fig. 6. Simultaneous and Time-dependent DNP-MRI Imaging of ${ }^{15} \mathrm{~N}$-carbamoyl-PROXYL and ${ }^{14} \mathrm{~N}-\mathrm{Tempol}$ in PBS

DNP-MRI images of ${ }^{15} \mathrm{~N}$ - and ${ }^{14} \mathrm{~N}$-nitroxyl radical were obtained with ESR irradiation at $456 \mathrm{MHz}$ or $480 \mathrm{MHz}$. FOV, $48 \times 48 \mathrm{~mm}$; matrix, $64 \times 64$; slice thickness, $10 \mathrm{~mm}$; TR/TE/TESR, 1200/25/600 ms. 

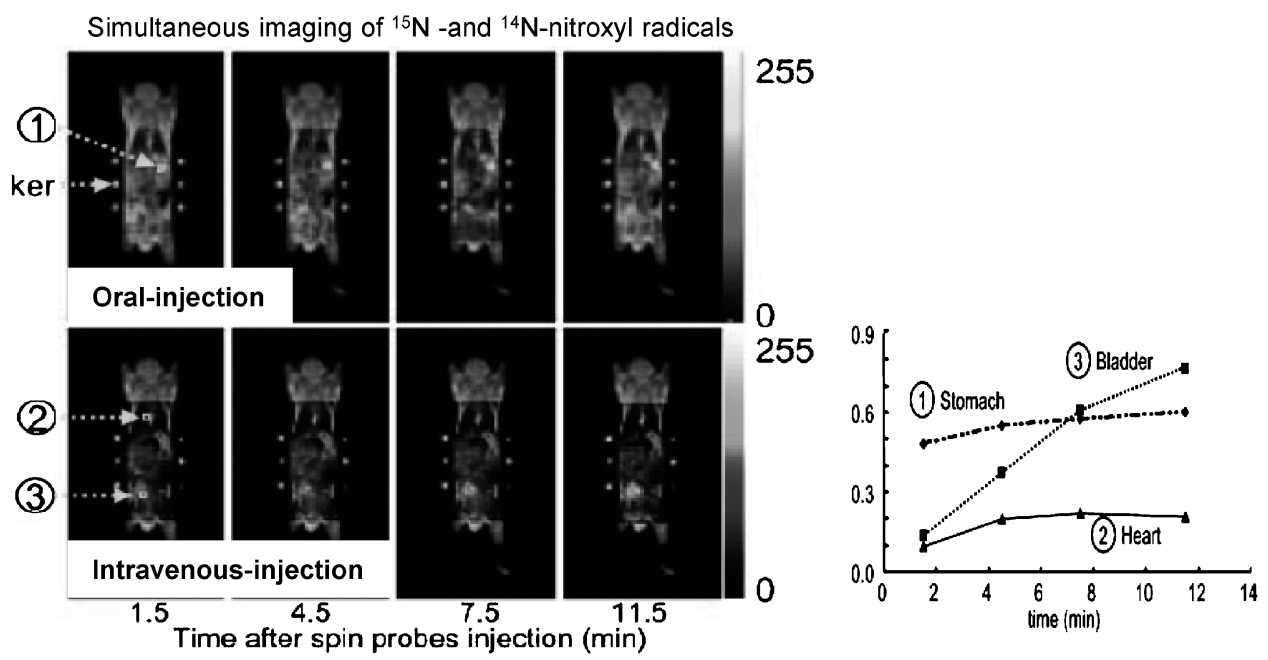

Fig. 7. Pharmacokinetic Images of ${ }^{14} \mathrm{~N}$ - and ${ }^{15} \mathrm{~N}$-nitroxyl Radicals after Injection through Different Routes

The time-dependent simultaneous images of ${ }^{15} \mathrm{~N}$-oxo-TEMPO and ${ }^{14} \mathrm{~N}$-carbamoyl-PROXYL in a living mouse after intragastrical and i.v. injection, respectively, and the time course of image intensities at stomach, heart, and bladder. $200 \mu \mathrm{L}$ of ${ }^{15} \mathrm{~N}$-oxo-TEMPO $(10 \mathrm{mM})$ was administered intragastrically, and then $200 \mu \mathrm{L}$ of ${ }^{14} \mathrm{~N}$-carbamoyl-PROXYL (300 mM) i.v. Immediately after administrations, DNP-MRI images of ${ }^{14} \mathrm{~N}$ - and ${ }^{15} \mathrm{~N}$-nitroxyl radicals were obtained. $\mathrm{T}_{1}$-weighted MRI was performed on a clinical MRI instrument, and the DNP-MRI images were superimposed with the MRI image by fitting the position of the markers (six capillaries containing either radical) (FOV, $48 \times 48 \mathrm{~mm}$; matrix, $64 \times 64$; slice thickness, $30 \mathrm{~mm}$; TR/TE/TESR, $1100 \mathrm{~ms} / 25 \mathrm{~ms} / 550 \mathrm{~ms}$ ). (Cited by Utsumi H. et al. Proc Natl Acad Sci USA. 2006 103 (5): 1463-8. 2006)

数を変えながら ESR 励起して画像化を行つた. 456 MHz で励起を行った場合には carbamoyl-PROXYL が充填されているファントムの画像強度が上昇し, ファントム(3)では carbamoyl-PROXYL と AsA の 反応によるラジカル消失に由来する画像強度の減少 がみられた。一方， $480 \mathrm{MHz}$ で電子スピン励起し た場合には, Tempol 由来ファントムが可視化さ れ，ファントム(3)では AsA との反応により画像強 度の減少が同様にみられた。 carbamoyl-PROXYL の場合では AsA 添加後 34 分においても画像強度を 得たが，Tempol の場合にはAsA 添加直後に画像 強度が消失した。これらの結果より DNP-MRI を 用いることで同じファントム内における 2 つのレド ックス反応を分離して解析することが可能であるこ とが本実験により示した.

Figure 7 には ${ }^{14} \mathrm{~N}$ と ${ }^{15} \mathrm{~N}$ 標識ニトロキシルラジカ ルを用いた分離画像化の動物実験の結果を示してい る. Figure 7 は ${ }^{15} \mathrm{~N}$ で標識した oxo-TEMPO を経口 投与， ${ }^{14} \mathrm{~N}$-carbamoyl-PROXYL を尾静脈内投与 後, 撮像した結果を示した. ここで胃と心臓, 膀胱 に関心領域を設定すると, 胃では ${ }^{15} \mathrm{~N}-\mathrm{oxo}-\mathrm{TEMPO}$

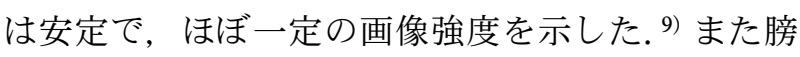
胱では尾静脈内投与された ${ }^{14} \mathrm{~N}$-carbamoyl-PROXYL の画像強度が経時的に上昇し膀胱に排泄される ことがわかった。

\section{5. まとめ}

本稿では磁気共鳴手法を用いた生体レドックス状 態の可視化について概説した. 磁気共鳴イメージン グは時間・空間分解能，生体深部計測，繰り返し測 定などいくつかの長所を有する一方, 光イメージン グや PET・SPECT など核医学イメージングに比べ 感度が低い点が克服すべき課題であると言える．本 稿で紹介した DNP は核スピンの信号強度を劇的に 上昇させることで MRI の感度を補間する方法であ る. 2000 年以降 DNP-MRIに関する研究が世界的 に拡大されており，われわれもオリジナル DNPMRI の開発, 新規イメージング法に関する研究を 進め，生体レドックス情報を中心する新たな診断・ 前臨床研究へ展開したいと考えている.

\section{謝辞本研究に際し, 九州大学先端融合医療レ} ドックスナビ研究拠点 江藤比奈子氏，中路睦子氏 には実験の遂行にご協力頂きました。ここに感謝い たします。また本研究は文部科学省地域産学官連携 科学技術振興事業費補助金・先端融合領域イノベー ション創出拠点形成プログラム, 日本学術振興会科 学研究費助成事業・基盤研究（A）（25253005）, 若 手研究 (A) (25713004), JST 研究成果展開事業, 先端計測分析技術・機器開発プログラム・実証・実 用化タイプのご支援で進められた研究でここにお礼 
申し上げます。

利益相反開示すべき利益相反はない.

\section{REFERENCES}

1) Murphy M. P., Biochem. J., 417, 1-13 (2009) .

2) Overhauser A. W., Phys. Rev., 92, 411-415 (1953).

3) Lurie D. J., Bussell D. M., Bell L. H., Mallard J. R., J. magn. Reson., 76, 366-370 (1988) .

4) Li H., Deng Y., He G., Kuppusamy P., Lurie D. J., Zweier J. L., Magn. Reson. Med., 48, 530-534 (2002).

5) Kosem N., Naganuma T., Ichikawa K., Phumala Morales N., Yasukawa K., Hyodo F., Yamada K., Utsumi H., Free Radic. Biol. Med., 53, 328-336 (2012).

6) Krishna M. C., English S., Yamada K., Yoo J., Murugesan R., Devasahayam N., Cook J. A., Golman K., Ardenkjaer-Larsen J. H., Subramanian S., Mitchell J. B., Proc. Natl. Acad. Sci. USA, 99, 2216-2221 (2002).

7) Matsumoto S., Yasui H., Batra S., Kinoshita Y., Bernardo M., Munasinghe J. P., Utsumi H., Choudhuri R., Devasahayam N., Subramanian S., Mitchell J. B., Krishna M. C., Proc. Natl. Acad. Sci. USA, 106, 1789817903 (2009).

8) Yamato M., Shiba T., Yamada K., Watanabe T., Utsumi H., J. Cereb. Blood Flow Metab., 29, 1655-1664 (2009).

9) Utsumi H., Yamada K., Ichikawa K., Sakai K., Kinoshita Y., Matsumoto S., Nagai M., Proc. Natl. Acad. Sci. USA, 103, 1463-1468 (2006).

10) Soule B. P., Hyodo F., Matsumoto K., Simone N. L., Cook J. A., Krishna M. C., Mitchell J. B., Free Radic. Biol. Med., 42, 1632-1650 (2007).

11) Soule B. P., Hyodo F., Matsumoto K., Simone N. L., Cook J. A., Krishna M. C.,
Mitchell J. B., Antioxid. Redox Signal., 9, 1731-1744 (2007).

12) Fujii H. G., Sato-Akaba H., Emoto M. C., Itoh K., Ishihara Y., Hirata H., Magn. Reson. Imaging, 31, 130-138 (2013).

13) Hyodo F., Soule B. P., Matsumoto K., Matusmoto S., Cook J. A., Hyodo E., Sowers A. L., Krishna M. C., Mitchell J. B., J. Pharm. Pharmacol., 60, 1049-1060 (2008).

14) Alecci M., Seimenis I., McCallum S. J., Lurie D. J., Foster M. A., Phys. Med. Biol., 43, 1899-1905 (1998).

15) Biller J. R., Tseitlin M., Quine R. W., Rinard G. A., Weismiller H. A., Elajaili H., Rosen G. M., Kao J. P., Eaton S. S., Eaton G. R., J. Magn. Reson., 242, 162-168 (2014).

16) Takeshita K., Utsumi H., Hamada A., Biochem. Biophys. Res. Commun., 177, 874880 (1991).

17) Yokoyama H., Lin Y., Itoh, O., Ueda Y., Nakajima A., Ogata T., Sato T., OhyaNishiguchi H., Kamada H., Free Radic. Biol. Med., 27, 442-448 (1999).

18) Hyodo F., Matsumoto K., Matsumoto A., Mitchell J. B., Krishna M. C., Cancer Res., 66, 9921-9928 (2006).

19) Brasch R. C., London D. A., Wesbey G. E., Tozer T. N., Nitecki D. E., Williams R. D., Doemeny J., Tuck L. D., Lallemand D. P., Radiology, 147, 773-779 (1983).

20) Brasch R. C., Nitecki D. E., Brant-Zawadzki M., Enzmann D. R., Wesbey G. E., Tozer T. N., Tuck L. D., Cann C. E., Fike J. R., Sheldon P., AJR Am. J. Roentgenol., 141, 10191023 (1983).

21) Matsumoto K., Hyodo F., Matsumoto A., Koretsky A. P., Sowers A. L., Mitchell J. B., Krishna M. C., Clin. Cancer Res., 12, 24552462 (2006).

22) Hyodo F., Murugesan R., Matsumoto K., Hyodo E., Subramanian S., Mitchell J. B., Krishna M. C., J. Magn. Reson., 190, 105-112 (2008) . 